\title{
Tourism and regional development as an expression of the globalization. Case.- Mexico-Cuba
}

\author{
Turismo y desarrollo regional como expresión de la globalización. Caso.- México- \\ Cuba
}

CAMELO-AVEDOY, José Octavio †*, RODRÍGUEZ-HERNÁNDEZ, Eusebio and RODRÍGUEZ ALVAREZ, Nely

Universidad Autónoma de Nayarit, Facultad de Economía. México.

$1^{\text {st }}$ Author: José Octavio, Camelo-Avedoy / ORC ID: 0000-0002-5722-3032, CVU CONACYT ID: 99469

$1^{\text {st }}$ Coauthor: Eusebio, Rodríguez-Hernández / ORC ID: 0000-0003-3829-0632, CVU CONACYT ID: 566794

$2^{\text {nd }}$ Coauthor: Nely, Rodríguez-Alvarez / ORC ID: 0000-0003-3130-2792, CVU CONACYT ID: 972018

DOI: $10.35429 /$ EJS.2020.13.7.17.28

Received July 21, 2020; Accepted December 12, 2020

\begin{abstract}
Tourism has been considered, in recent years, as a strategy for creating tourist regions, to meet local and international demand; Tourism activity has been considered an ideal one to incorporate national regions into global market dynamics. Starting with tourism, countries seek to incorporate the benefits of global currency mobility. In turn, incorporate the resident population of the region into employment or underemployment, as a government policy. This research focuses on the detection of the most iconic regional points of the Mexican and Cuban republic, based on their development of tourist activity, and their links, as a central element of economic dynamics. The foregoing, framed from globalization as a factor of integration of tourist regions. Cross-sectional study, with an explanatory scope; The objective is to expose the most relevant tourist regions of the two countries, as well as their economic dynamics in the region. The document that is exposed is a second installment of a larger investigation that is in the process of being concluded.
\end{abstract}

Tourism, Regional development, Enclave regions, Globalization

\begin{abstract}
Resumen
El turismo se ha considerado, en los últimos años, como estrategia de conformaciones de regiones con dicha orientación productiva para atender la demanda local, pero también internacional; se ha considerado la actividad turística, idónea, para incorporar regiones nacionales a dinámicas del mercado global. A partir del turismo, los países buscan incorporarse a los beneficios de la movilidad global de las divisas. A su vez, incorporar al empleo o sub empleo a la población residente de la región, como una política de corte gubernamental. La presente investigación se centra en la detección de los puntos regionales más icónicos de la república mexicana y cubana, a partir de su desenvolvimiento de la actividad turística, y sus eslabonamientos, como elemento central de dinámica económica. Lo anterior, enmarcado desde la globalización como factor de integración de las regiones turísticas. Estudio de corte transversal, de alcance explicativo; el objetivo es exponer las regiones turísticas más relevantes de los dos países, así como su dinámica económica en la región. El documento que se expone es una segunda entrega de una investigación de mayor envergadura y que se encuentra en proceso de conclusión.
\end{abstract}

Turismo, Desarrollo regional, Regiones enclaves, Globalización

Citation: CAMELO-AVEDOY, José Octavio, RODRÍGUEZ-HERNÁNDEZ, Eusebio and RODRÍGUEZ ALVAREZ, Nely. Tourism and regional development as an expression of the globalization. Case.- Mexico-Cuba. ECORFAN Journal-Spain. 2020. 7-13: 17-28.

\footnotetext{
* Correspondence to Author (Email: ocameloa@uan.edu.mx)

$\uparrow$ Researcher contributing first author.
} 


\section{Introduction}

The economies of the countries, in the current economic logic, is to seek an increase in production, that is, in any of the three sectors; but, sometimes the economies seek to encourage the participation of a particular branch or economic activity, as a strategy to generate regional development processes through a point and enclave activities that radiate productive dynamism to the region in question.

Tourism has been considered, by various countries, as an economic space which can be translated into taking advantage of the potential that it has, whether of a natural nature or culture, and derived from it a diversity of tourism typologies, to name a few : sun and beach, historical, gastronomic, ethnographic, among others. In this way, it turns particular regions into enclave points where tourist activity permeates socio-economic dynamism.

This document aims to highlight, according to the research, the most relevant tourist enclaves of two countries that have turned tourism as a source of regional socio-economic dynamism, such as the Mexican and Cuban republics. The detection of the main tourist regions exposed is based on the positioning criteria of the regional destination and its contribution to economic dynamics.

The document is made up of a first section entitled: contextual framework, which explains the changing conditions that the global economic context in which the research began (prior to the COVID-19 pandemic) and how tourism experiences some situations in the current pandemic; the second item refers to the theoretical framework, where the exposition of the concepts and categories handled is presented;

The third chapter has been titled -the key tourist regions of Mexico- where an exposition of those regions that have been considered the most outstanding is made; the next item is titled -the key tourist regions of Cuba-, which revolves around what is considered the main tourist regions of Cuba; finally, some brief conclusions are presented.

\section{Contextual framework}

Tourism has been the source of various studies during the post-war period to the present day, and even some countries or regions have turned to strengthening their infrastructure and destinations to be positioned in the local and international market, Mexico was no exception, and Cuba, after its revolution and established the new economic and government order of the new republic, spent a few years making tourism a source of income and positioning its destinations in the international market. But there are even destinations that the total of their economic dynamics is related to tourism, it is enough to turn to observe the Canary Islands.

In 2019, global mobility related to tourism increased, according to the World Tourism Organization (UNWTO) (2019) tourism amounted to 1.4 billion international tourists in the world, $5 \%$ more than in 2018 The same UNWTO indicates that there was a mobility of dollars, for tourist activities, in the world of 1.7 billion, which represents an increase of $4 \%$ compared to the previous year.

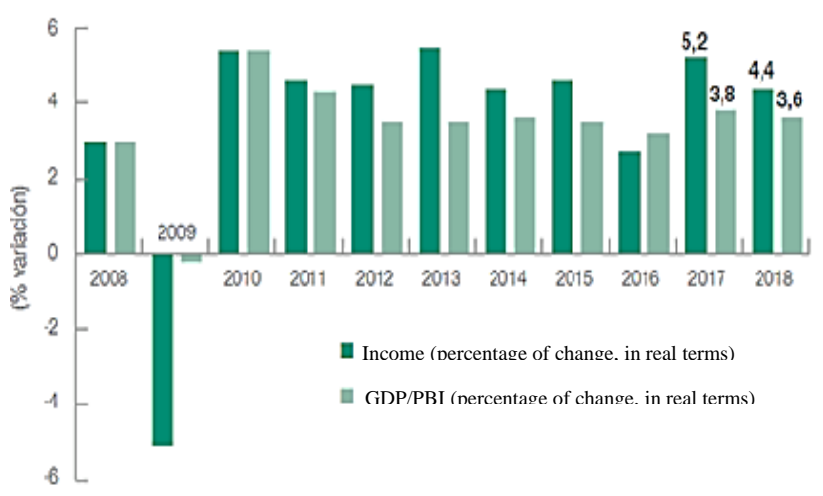

Graphic 1 World tourism income and world GDP (\% variation)

Source: UNWTO (2019), with data from: UNWTOUNWTO and the International Monetary Fund

Seen from a recent historical perspective, it is observed that tourism activity has a significant foreign currency collection in the world, in particular by the different world tourist regions. However, at the beginning of the year 2020, a virus, known as COVID-19, has been presented, which has unleashed a pandemic and has had immeasurable consequences in the tourism sector, and many more, which has caused tourism activity to be strongly affected. reverse.

When starting the preparation of this research, the global economic dynamics will proceed normally, with some signs of economic conflict in different regions, to name a few: the U.S.- China tariff war, Brexit in Europe, the conflict with the $5 \mathrm{G}$ Network. 
But the tourist activity seemed to advance smoothly; However, at the beginning of the year 2020, the SARS-CoV-2 virus appears, which has turned the world economy around, with too strong an impact on tourist activity. It is in this historical framework that this research remains between the past and the present of COVID-19.

According to data from the Economic Commission for Latin America and the Caribbean (ECLAC) (2020), the socio-economic impacts of the pandemic will be pressing, but in particular as regards tourism, it states that "Tourism It has been one of the sectors most immediately affected by COVID-19 in the region. The effects have been particularly intense in the Caribbean, where, for several economies, tourism receipts represented more than $20 \%$ of GDP in $2018 "$ ( $/$ p).

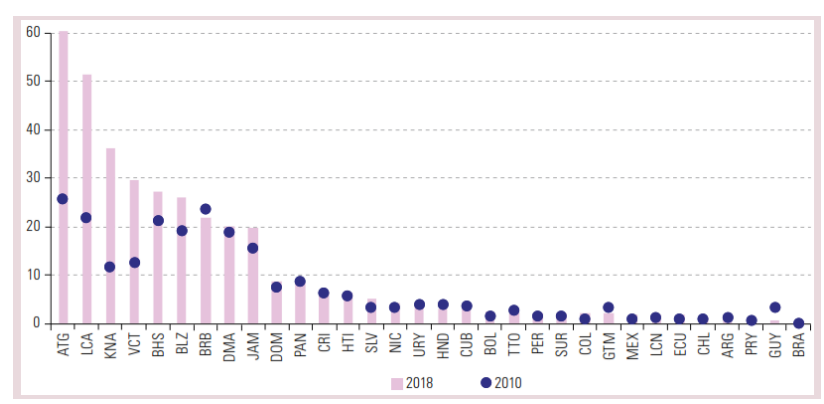

Graphic 2 Percentage of the share of tourism revenues in GDP, 2010 and 2018

Source: ECLAC (2020)

According to the economic scenarios handled by ECLAC itself (2020), as the magnitude of the impact is still uncertain, it exposes some considering the fall in tourism activity and its impact on GDP. Obviously, he leaves the rest of the variables in Ceteris paribus, "In a scenario with a $10 \%$ drop in tourism, in 2020, GDP would decrease by $0.8,0.3$ and 0.1 percent in the Caribbean, Mexico and Central America, and South America, respectively. In a more negative scenario where tourism revenue decreased $30 \%$, in 2020 , the drop for these subregions would be $2.5,0.8$ and 0.3 percentage points, respectively. The repercussions on employment, household income and government income would be greater in the Caribbean, where this sector employs about 2.4 million people and represents $15.5 \%$ of GDP "(s / p)

Given the magnitude of the impact of the COVID-19 pandemic, it would be worth bearing in mind that the research being provided would undergo a change in the present and future, it will be a matter of beginning to publish the data in this regard.

\section{Theoretical framework}

Much has been written about globalization, as an abstract social space, development of the economy and circulation of goods and capital; In this aspect, there are different dimensions of participation in globalization, as a recipient of goods and capital, and as an exporter of goods; the most finished products, with the greatest value chain, or those that are limited to the primary exporter; but globalization, then, in its greatest characterization, occurs in the order of mobility of goods and capital, but not in the mobility of the labor force; Globalization takes its most concrete form in the form of commercial treaties, as stated in Vidal (2016), in these treaties, which have an implication of legal agreement, the rules are established under which the transaction of goods is formed, and eventually of the workforce. Investment capitals are those that are freest to participate in global investments, since according to Robinson (2013) it is internationalized, regardless of its country of origin and regardless of the destination country, but the possibility of their mobility and obtaining the benefit.

But this global dynamic has its specific expression in the regional. When speaking of Regional Development, implicit remains, from this focus of the present investigation, to the economic activity that can be promoted and / or linked by carrying out a process of regional economic integration;

"the origin of regional development as
theory and methodology comes strictly from
the economic field. Although its conceptual
base is empiricist and with a strong
neoclassical burden, from the 1940s
onwards, social problems were understood
as a result of economic conditions, and with
it, regional inequalities are addressed not
only from an economic perspective, rather,
they acquire a social-historical-
anthropological approach [...] the region
cannot be conceived in itself. That is, the
features, whether of homogeneity or
heterogeneity, of a region where infinity of
vertical and horizontal relationships are
linked are identifiable only if there is an
opposite that has different features, or the
same features, but quantitatively different
from the region with the one that compares"
(Villa, 2003, p. 11).

"the origin of regional development as theory and methodology comes strictly from base is empiricist and with a strong neoclassical burden, from the 1940s onwards, social problems were understood as a result of economic conditions, and with are addressed not pocial-historicalanthropological approach $[\ldots]$ the region cannot be conceived in itself. That is, the features, whether of homogeneity or heterogeneity, of a region where infinity of vertical and horizontal relationships are linked are identifiable only if there is an opposite that has different features, or the (Villa, 2003, p. 11). 
Thus, reference is made to production, regardless of the sector or branch of economic activity. In any case, production presupposes, by definition, a process of appropriation / transformation of nature, whether in the form of a tangible and transportable satisfactor, to the place of consumption; Or, be it in the form of intangible and non-transportable, with the buyer having to consume the product in the region itself, such as tourism.

The region is thus shaped by a process of valorization of production,

"It is a valuation space in that it expresses the concrete (empirical) forms of capitalist production and reproduction and with it the form that capital accumulation takes. The region seen in this way implies movement, that is, the historical process of the valuation space [...] Capitalist production is transformation of the natural environment and at the same time it is the mechanism of appropriation of this natural environment by capital [.. .] Talking about the valuation space also means talking about the presence of value systems in the ethical, moral and cultural sense, which will be accompanied by the presence and characteristics of capital accumulation in a given space." (González y Villa, 2003, p. 92)

It is the region, as a space for valorization, where the social relations of production in particular, of the region are created, establishes historical processes, and therefore the modification of these social relations of production,

"The region seen as the consequence of an economic-historical-social conformation, means that the culture, norms, values, among other aspects of identifying a region, can be considered, from the political economy, that its origin is considered as a cause of the gestated process to establish the general conditions of capital accumulation of said region, of the extraction of resources from the territory, of a process of social production" (Camelo, 2014, p. 31)

It is, then, the region, with dynamic characteristics; therefore, the socio-economic region determines itself in the historical process.

\begin{abstract}
"The evolution and construction of economic contexts are of a historical nature, it allows establishing a process of re-construction of the general conditions of capital accumulation under which a certain economic context was established, that is, it is the material analysis of history what this evolution shows. But before this, it should not be extracted, but on the contrary, complement, that the economy, and especially if the history is analyzed, is dialectical in nature, it is not linear under the one-to-one idea, it allows us to search for the multiple contradictions, in its dynamic expression, that configure a certain historical context that results in the emergence of a set of elements that allow the object of study and analysis to be explained" (Camelo y Rodríguez, 2018, p. 16)
\end{abstract}

All the composition of relations in the production process, of satisfactors, generate the integration and conformation of the region, regardless of the economic orientation that it was; in turn, said valorization of production also establishes the conformation of the regional identity.

The region, being of diverse orientation, depending on the objective of the research or application of the program or policy in question, exists the tourist region, the one in which its social relations of production are oriented to make tourism its productive orientation. Thus, there is a vast literature that refers to the conceptualization and definition of tourism, but none of these integrates the needs that society currently requires.

In this section, different conceptualizations by various authors and some international tourism organizations are analyzed, with the purpose of reaching a conclusion that is clearer and more precise.

Before describing tourism, first, it is necessary to know its etymological roots. According to De la Torre (1997) the word tourism is derived from the roots tour and turn that come from the Latin, either from the noun tornus ("lathe") or from the verb tornare ("to turn", in vulgar Latin), whose connotation would be synonymous with "circular trip".

A good part of the content of the following definitions are expressed by authors such as: Schullern, Glückmann, Morgenroth, Bormann, Stradner and Troisi among others, who were part of the "Berlin school" in the period from 1911 to 1939 , that is, before of the first and second world war. 
The first author to define tourism from an economic perspective was Hermann von Schullern zu Schrattehofen (1911 in Muñoz, 1992). Tourism is the set of all those processes, especially economic ones, that set arrivals, stays and departures in motion. of tourists to and from a specific community, region or state and that are directly related to them "(p. 19). For Glucksmann (1930, in Muñoz, 1992), an expiration of the space made by individuals who access a locality in which they do not have their residence "(p. 29). According to Morgenroth, (1929, in Fuentes, 2016) tourism is an activity that takes the traffic of people who leave their habitual place of residence to another place and there satisfy needs of various kinds. (p. 107) Borman, (1930, in Cortés \& Muñoz, 2016) defines tourism as "The set of trips whose object is pleasure or commercial, professional or other similar reasons and during the which the absence of the resi habitual dencia is temporary "(p. 9). At the same time, Stradner (1920, in Fuentes, 2016), tourism is a graph of luxury travelers, that is, of those who leave their habitual residence and go elsewhere without any economic purpose, but to increase their "Status" and satisfy luxury needs (p. 107). The Swiss Hunziker and Krapf, (1942, in Viloria, 2012). Likewise, the founders of the humanistic school defined tourism "a set of relationships and phenomena produced by the displacement and temporary stay of people outside their habitual place of residence, without being motivated by profit" ( $\mathrm{p}$. 26). Magliulo, (2015 in Troisi, 1942) It is conceived as a heterogeneous set of acts of demand and consumption carried out by outsiders in a place of reference, such set gives rise (or is answered) by an equally heterogeneous set of goods and services produced in said place. (P. 34). Professor De Arrillaga, (1955, in De la Torre, 1997) tourism is all temporary displacement, determined by causes other than profit; the set of goods, services and organization that these movements determine and make possible in each nation, and the relationships and events that take place between them and the travelers (Page 15).

For the Montecarlo International Tourism Academy in its International Tourist Dictionary (1970 in De la Torre, 1997) "term that refers to pleasure travel and the needs of the tourist" (Pag. 15). In a more recent era, the World Tourism Organization (1994 in Sancho, 1997), "tourism comprises the activities that people carry out during their trips and stays in places other than their usual environment, for a consecutive period of time less than one year, for leisure, business and other purposes "(p. 11).
Mathieson and Wall (1982 in Sancho, 1997) used a definition very similar to the previous one, although with some modifications: "Tourism is the temporary movement of people, for periods of less than a year, to destinations outside the place of residence and work, the activities undertaken during the stay and the facilities created to satisfy the needs of tourists "(p. 46). For Acerenza (1986), he refers to a universally accepted definition, given by Hunziker and Krapf in 1942, noting "tourism is the set of relationships and phenomena produced by the displacement and permanence of people outside their place of residence, in so much so that said displacements and permanence are not motivated by a main lucrative activity, permanent or temporary "(p. 24). For Jafari \& Ritchie (1981 in De la Torre 1997), tourism is a study of man far from his habitual habitat, of industry, which responds to his needs and the impacts that both he and industry have on sociocultural environments, economic and physical (p. 15). De la Torre (1997) has arrived at a more comprehensive definition that manifests the complexity of the tourist phenomenon and its contemporary character, accepted by all tourism scholars:

"Tourism is a social phenomenon that consists of the voluntary and temporary displacement of individuals or groups of people who, mainly for reasons of recreation, rest, culture or health, move from their usual place of residence to another where they do not carry out any activity. lucrative or remunerated, generating multiple interrelationships of social, economic and cultural importance." (Pag.16).

Of all the definitions previously exposed, it should be noted that the conceptualization of Hunziker and Krapf (1942), Jafari \& Ritchie (1981) and De la Torre (1997), are those that most closely approximate the reality in which we live. Elements that are common to all of them also stand out, such as: the physical movement of people, the stay at the destination, the activities carried out during the stay and the satisfaction of tourists' needs.

Currently, the concept of tourism proposed by the economic sectors, by capital, has lost the initial romanticism, and this socioeconomic phenomenon has been studied, legislated and exploited; reason why today different types of tourism are established, destined for different audiences according to their purchasing power, economic, their tastes, their preferences, concerns, etc. 
So we can find different types of tourism. According to the classification of the tourist modalities according to the reason for the trip, they are: traditional, sun and beach tourism; and, alternative tourism, which integrates ecotourism, adventure tourism and rural tourism.

Traditional or massive tourism, according to Ibáñez \& Cabrera (2011), is considered as all those massive flows of human beings of all ages and conditions, precedent of the big cities, that move synchronously at certain times of the year, with destination to supposedly paradisiacal places.

Alternative tourism, according to SECTUR (2004), are those trips that aim to carry out recreational activities in direct contact with nature and cultural expressions that surround it with an attitude and commitment to know, respect, enjoy and participate in conservation. of natural and cultural resources; This definition has, in turn, facilitated a segmentation of alternative tourism, based on the type of interest and activities that the tourist has and seeks when being in contact with nature. The Ministry of Tourism has divided Alternative Tourism into three large segments, each consisting of various activities, where it is worth mentioning that any of the activities defined below may require specialized guides, techniques and equipment:

Ecotourism.- One of the most widely adopted definitions of "ecotourism" is that proposed by Ceballos Lascuraín (2007 in Guerrero, 2010) as: That environmentally responsible tourist modality consisting of traveling or visiting natural areas $[. .$.$] in order to$ enjoy, appreciate and study the natural attractions (landscape, wild flora and fauna) of these areas, as well as any cultural manifestations (present and past) that may be found there, through a process that promotes conservation, has low environmental impact and Cultural $[. .$.$] constitutes a social and economic$ benefit for local populations (Pag. 41).

Adventure trip. - SECTUR (2004) defines Adventure Tourism as: The trips that are intended to carry out recreational activities, associated with challenges imposed by nature. (P. 22).

Rural tourism.- SECTUR (2004) defines this segment as: The trips that have the purpose of carrying out activities of coexistence and interaction with a rural community, in all those daily social, cultural and productive expressions of it (Page 29).

\section{The key tourist regions in Mexico}

\section{Main tourist regions of Mexico and their characteristics}

Fragmenting the country's territory is a strategy that allows regions to be built from local products that can be complemented to position a tourist region that can compete with other regions at the national and international level, in a word, to make a regional tourism product (ToseeMéxico , 2010, p. S / n). The tourist regions of Mexico are made up of 12 tourist zones with the purpose of studying their geographical spaces, identifying areas of opportunity for the use of its natural and cultural resources and contributing to the tourist development of the country. According to ToseeMéxico (2010), these twelve tourist areas and the states that compose it will be described below:

"1.- Yucatan Peninsula: the northern part of the peninsula, with coast to the Gulf of Mexico, includes the states of Yucatan and Campeche, 2.- Mexican Caribbean: located in the southern and southeastern part of the Yucatan Peninsula, covers the state of Quintana Roo, 3.- Gulf of Mexico: It includes the states of Tabasco and Veracruz, 4.- South Pacific: it includes the states of Chiapas and Oaxaca, 5.- Mexico City: Mexico City, before the DF, 6.- Central Pacific: it includes the states of Guerrero, Michoacán, Colima, Jalisco and Nayarit, as well as the southern part of Sinaloa, 7.Northeast: it includes the states of Tamaulipas, Nuevo León and Coahuila, 8.North Central: it includes the states de Chihuahua and Durango, 9.- Baja California: comprises the states of Baja California and Baja California Sur, 10.- Northwest: comprises the states of Sonora and Sinaloa (the northern and central parts of the state), 11.- Center: Comprrende the states of Zacatecas, San Luis Potosí, Aguascalientes, Querétaro and Guanajuato and 12.- Centro $\mathrm{Su}$ A: It includes the states of Hidalgo, Estado de México, Puebla, Tlaxcala and Morelos (ToseeMéxico, 2010, p. y/n).

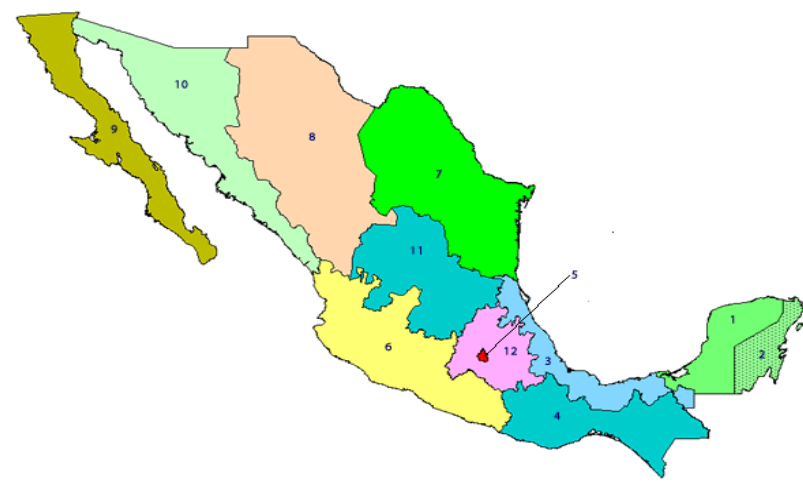

Figure 1 The tourist areas of Mexico

Source: https://www.toseemexico.com/destinos-turismomexico.htm

CAMELO-AVEDOY, José Octavio, RODRÍGUEZHERNÁNDEZ, Eusebio and RODRÍGUEZ ALVAREZ, Nely. Tourism and regional development as an expression of the globalization. Case.- Mexico-Cuba. ECORFAN Journal-Spain. 2020 


\section{Dynamics and economic relevance}

In the following section, the main results of the tourist activity in Mexico will be analyzed, which contains the main statistics based on 70 tourist destinations in the country and its tourist flows and variables such as: international travelers, domestic, air and sea tourism, tourism activities. accommodation, which together offer a perspective of the dynamics of the tourism sector in Mexico. The results of the tourist activity for the month of January 2020 are described below:

According to SECTUR, (2020), the arrival of international visitors was 8 million 421 thousand, this is 497 thousand more visitors compared to the same period in 2019, which represented an increase of $6.3 \%$; the arrival of international tourists to Mexico was 3 million 795 thousand, a level higher by 313 million than that observed in the same period of 2019 and equivalent to an increase of $9.0 \%$; Foreign currency inflow by international travelers was 2,282 million dollars, which represented a reduction of (-) $0.3 \%$ compared to the same month of 2019; the average expenditure of tourists admitted by air was \$ 1,030.3 during January 2020, which represented a reduction of (-) $4.1 \%$ compared to that observed in the same month of 2019; the departure of international tourists from Mexico was 1,550,000 international tourists, which meant 6,573 more tourists compared to the number of tourists who left in the same month of 2019, equivalent to an increase of $0.4 \%$, foreign exchange spending by travelers residing in Mexico abroad was 819 million dollars during January 2020, lower by 94 million 333 thousand dollars than that observed in the same month of 2019 and equivalent to a reduction of (-) $10.3 \%$, the foreign exchange balance by International visitors registered a surplus of one thousand 463 million dollars, an amount $6.3 \%$ higher than that observed during the same month of 2019 , foreign visitors by air (main countries by nationality) United States, representing $49.3 \%$ of the total, as well as from Canada with $20.7 \%$.

While the European region had a $10.8 \%$ share in the total, $1.8 \%$ corresponding to citizens of the United Kingdom. South America represented $11.4 \%$ of the total, where the citizens of Colombia and Brazil participated with $3.1 \%$ and $2.3 \%$ of the total, respectively, during the same month, foreign visitors by air (main countries by residence) United States, representing $52.9 \%$ of the total, as well as Canada with $21.3 \%$.
While the European region registered a participation of $9.4 \%$, with residents of the United Kingdom representing $1.7 \%$ of total arrivals by air, while South America represented $10.1 \%$ of the total, where residents of Colombia and Brazil participated with $2.6 \%$ and $2.1 \%$ of the total, respectively, passengers with United States nationality (by air) recorded an increase of $7.6 \%$ during January 2020, adding 879 thousand 610 passengers, most of whom arrived at airports Cancun and Los Cabos, passengers with Canadian nationality (by air) recorded a growth of $3.2 \%$ during January 2020, compared to the same period in 2019, registering 369 thousand 363 passengers, most of whom arrived at Cancun and Puerto Vallarta airports, passengers residing in the United States (by air) registered an increase of $8.5 \%$ during the month of January 2020, adding 905 thousand 624 passengers, most of whom arrived by air Cancun and Los Cabos ports, passengers residing in Canada (by air) recorded a growth of $1.7 \%$ during the month of January 2020 compared to the same month in 2019, registering 364 thousand 124 passengers, most of whom arrived According to the Cancun and Puerto Vallarta airports, the main airports that received the largest number of foreign visitors in Mexico were, according to their nationality:

- $\quad$ Cancun $(738,933)$

- $\quad$ Mexico City $(406,562)$

- $\quad$ Puerto Vallarta $(196,302)$

- $\quad$ Los Cabos $(166,549)$

- $\quad$ Guadalajara $(94,172)$

- $\quad$ Mazatlán $(22,555)$

- $\quad$ Monterrey $(21,769)$

- $\quad$ Cozumel $(21,150)$
CAMELO-AVEDOY, José Octavio, RODRÍGUEZHERNÁNDEZ, Eusebio and RODRÍGUEZ ALVAREZ, Nely. Tourism and regional development as an expression of the globalization. Case.- Mexico-Cuba. ECORFAN Journal-Spain. 2020 
The percentage of hotel occupancy in the group of 70 tourist centers, during January 2020, was $57.2 \%$, a level higher by 2 tenths of a percentage point compared to that observed during the same month of 2019, the arrival of national tourists to hotel rooms reached 4 million 654 thousand tourists ( $68.9 \%$ of the total); While 2 million 102 thousand were international tourists $(31.1 \%$ of the total), in air transportation the total arrival of passengers via road was 6 million 749 thousand passengers, which represents an increase of 529 thousand 67 passengers, equivalent to $8.5 \%$ with respect to At the same period of 2019, the arrival of passengers on domestic flights was 4 million 430 thousand passengers, which represents an increase of 417 thousand passengers $10.4 \%$ compared to that observed in the same period of 2019, in air transportation the arrival of passengers on international flights was 2 million 320 thousand people, which represents an increase of 112 thousand 62 passengers compared to 2019, sea transportation the number of passengers on cruise ships that arrived was One million 84 thousand passengers, exceeding 113 thousand 344 passengers to those registered in the same period of 2019, the number of cruises that reached our destinations was 391 cruises, which represented an increase of 46 cruises, equivalent to an increase Of the $13.3 \%$ compared to the same period in 2019 , the main ports that received the highest number of cruise passengers in Mexico were:

Cozumel, Majahual, Puerto Vallarta, Cabo San Lucas, Ensenada and Progreso, which represented $92 \%$ of total passengers and in visitors to museums and archaeological zones the National Institute of Anthropology and History reported the arrival of 2 million 614 thousand visitors, that is, 33 thousand 849 fewer visitors than reported in the same period of 2019, which represented a decrease in (-) $1.3 \%$. Of the total number of visitors, $74.7 \%$ corresponded to national visitors and $25.3 \%$ to foreigners (SECTUR, 2020).

Therefore, it is observed that the arrival of international tourists to Mexico is increasing year by year and the activities of domestic tourism are greater, as well as the influx of tourists by air, especially at the Cancun airport, Quintana Roo. ; in the same way, the hotel rooms are insufficient for the tourism that is received. All of the above implies that Mexico must increase, improve and diversify its tourism products and services, being these competitive for the generation of higher income from tourism in our country. However, there is something that should be analyzed in greater detail, it is the contracting behavior in spending generated by tourists in the country.

\section{The key tourist regions in Cuba}

Tourism development in Cuba, in recent years, has been concentrated in eight prioritized regions, which are: Havana, Varadero, Jardines del Rey, Norte de Camagüey, Norte de Holguín, Santiago de Cuba, Costa Sur Central, and Los Canarreos, a which has been added in recent years to the northern region of Villa Clara. In addition, it is in these regions where the main attractions and infrastructure to support tourism are concentrated, as well as the main investments (Chávez, Chávez, \& Cerdan, 2019, p.36). Of these regions, the ones considered most essential are discussed below.

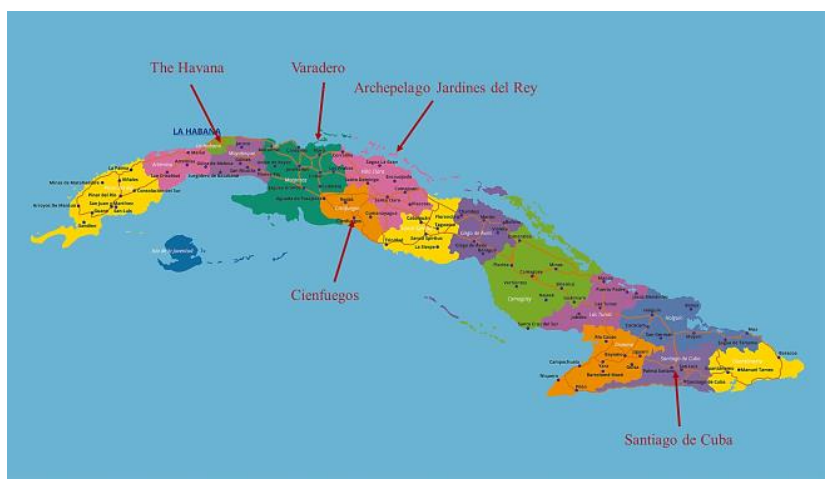

Figure 2 Some of the main tourist regions of Cuba

Source: own elaboration with Google map and own data

First of all, there is Havana, the capital of Cuba and the main tourist destination in the country, "it was founded in 1519 under the name San Cristóbal de La Habana, it is located in the western part of Cuba. It is the smallest province of the 15 that divide the country, however, it is the most populated with 2,154,454 inhabitants, about $20 \%$ of the country's population, for a population density of 2,958.4 inhabitants per square kilometer "( Pérez, 2014, p.225). Thanks to the work carried out by the City Historian's Office, with the representation of Dr. Eusebio Leal Spingler, an intense work of conservation, reconstruction and care of the heritage area of Old Havana has been carried out.

As a tourist destination, " $65 \%$ of total income for this concept enters the country. Old Havana was declared a cultural heritage of humanity in 1982 so there are two wellidentified tourist areas: the historic center of the city and its system of fortifications, which are the main tourist attraction and the setting for tourism development. cultural or congresses and events. On the other, the east coast, whose main vocation is sun and sand, although its participation is low, only represents $0.6 \%$ of the country's total income" (ONEI, 2012, as cited in Pérez, 2014, p.225).
CAMELO-AVEDOY, José Octavio, RODRÍGUEZHERNÁNDEZ, Eusebio and RODRÍGUEZ ALVAREZ, Nely. Tourism and regional development as an expression of the globalization. Case.- Mexico-Cuba. ECORFAN Journal-Spain. 2020 
Varadero beach is the second tourist destination in the country, "it is located in a geographical accident approximately 20 kilometers long, on the north coast of the Matanzas province, second in territorial extension in Cuba. [...] Varadero is the most important tourist pole of sun and beach in the country. In it, areas of sun, sand and beach converge, urban spaces with a population density of more than 500 inhabitants per $\mathrm{km} 2$ and the ever-decreasing natural spaces" (Moya, Cabrera, Castillo \& Rojo, 2007, p.38).

Varadero beach is considered one of the most beautiful in the world and the arrival of visitors annually is considerable, which is why the country has made large investments in hotel infrastructure and others linked to tourism there. For the same reason, "it is also the second in income to the country, receiving since 2014 more than 1 million tourists a year [...]. Currently, it has a hotel capacity of more than 50 hotels, and more than 20,500 rooms, the management of which results in revenues of more than USD 500 million and profits of more than USD 300 million. It is distributed among the MINTUR companies: Cubanacán, Gran Caribe and IslaAzul, and a large number of Gaviota hotels that belong to the Business Administration Group (GAESA) of the Ministry of the Revolutionary Armed Forces (MINFAR). A good part of them have foreign participation, being regulated through the Foreign Investment Law (No. 118/2014)" (Rodríguez, 2017, p. S / n).

At the end of the eighties, Commanderin-Chief Fidel Castro Ruz, proposed the idea of expanding tourism development by taking it to the northern cays of Cuba, with beautiful areas of virgin beaches and white sands. of the most important tourist destinations in the country.

"Jardines del Rey, located in the northern keys of the Ciego de Ávila province, where the Cayos Coco and Guillermo stand out, which can be accessed by a stone jetty over the sea and an international airport in Cayo Coco, these cays of extraordinary beauty and Landscaping diversity reveal what nature has created for centuries throughout history. In this destination, a wide range of four- and five-star category hotels are installed, basically all on the beachfront." (González, Ahu, Sori \& González, 2019, p.114).

On the other hand, located in the easternmost area of Cuba, is the province of Santiago de Cuba, also one of the relevant sites in Cuban tourism, which stands out for both its heritage and its history (closely linked to the struggles Cuban independence), as for its exotic mountain landscape.
"Its city was founded in 1515 by Diego Velázquez and was the last of the seven towns in Cuba. Its historic urban center is considered a monumental complex due to the large number of sites and buildings that have been declared National and Local Monuments. The city also holds the title of Hero City of the Republic of Cuba, as well as the Antonio Maceo Order, for its contribution to the independence struggles and the strong tradition of struggle of its inhabitants [...] Santiago de Cuba is the second city in importance of the country, its location on the south eastern coast of Cuba gives it the existence of beautiful landscapes, both in the city and in its natural environment. For this reason, it has tourism potential and sustained work in this area, highlighting the efforts being made for sustainable development, especially in the protection of natural resources." (Baños, 2008, p. s/n).

Regarding its physiography and comfort "Sierra Maestra stands out in its geography, the largest mountainous group on the island, with $243 \mathrm{~km}$ of extension and areas of great ecological value such as the Baconao Biosphere Reserve; high mountains of excellently preserved landscapes, valleys, rivers [...]. They also highlight high-standard accommodations and a perfectly equipped Convention Center. Nautical activities, cruising and health and quality of life tourism are possible in the territory" (Ministry of Tourism of Cuba, 2020).

As a relevant site to mention for Cuban tourism is also Cienfuegos, "a state that occupies a privileged position in the south center of Cuba, which forces its passage to tourists, both national and international. It limits the north with the provinces of Villa Clara and Matanzas. To the east with the municipality of Manicaragua (province of Villa Clara) and with the municipality of Trinidad (province of Sancti Spíritus). To the south it limits with the Caribbean Sea and to the west with the municipalities Ciénaga de Zapata and Calimete, in the province of Matanzas" (Ministry of Tourism, 2018).

Tourism in Cienfuegos has had a considerable increase in recent years, since it stands out for its cultural, heritage and natural resources. "Its capital city bears the same name, it has a Historic Center recognized by UNESCO as Cultural Heritage of Humanity since 2005. It is the only Cuban city that was founded by the French, so its environment and architecture is characterized by a style Frenchified, which even today is perfectly preserved, it has a cultural richness characterized by folk dances, singing and painting" (Ministry of Tourism, 2018).

CAMELO-AVEDOY, José Octavio, RODRÍGUEZHERNÁNDEZ, Eusebio and RODRÍGUEZ ALVAREZ, Nely. Tourism and regional development as an expression of the globalization. Case.- Mexico-Cuba. ECORFAN Journal-Spain. 2020 
"The state also has various natural attractions such as: beaches, mountains, rivers and caves" (Ministry of Tourism, 2018).

Due to the aforementioned characteristics, both national and international tourist demand is very high. "National tourism comes from all the regions of the country that visit it to know its cultural wealth and to fundamentally enjoy its beaches. As for international tourism, all the existing tourism modalities are demanded such as sun and beach tourism, hiking, cultural and heritage tourism and the main countries that bring tourists to the country are: Canada, Germany, France, United Kingdom, Spain, Switzerland, Holland and Italy, mostly cold countries that travel to Cuba mainly in the months between mid-December and mid-March, as well as the months of July and August, looking for the warm climate that this region offers "(National Statistical Office and Information, 2019).

\section{Conclusions}

There are regions in Mexico and Cuba that make tourism a preponderant activity, not only in itself, but in the direct and indirect economic ties that the tourist activity generates.

The impact of the pandemic has made it visible that economic regions must have more than one economic activity that drives regional dynamism, as there are mono-productive regions, for the present case, of tourism, at times like the present one, in the midst of a pandemic COVID-19-2020, show the undesirable side of the mono-productive orientation of the region. With its social repercussion derived from the economic contraction.

It is observed that the enclave points of tourism, in Mexico and Cuba, have a distribution throughout the territory, and strategically, ends of the territories and center of the same, where it concludes that the tourist enclaves points of both countries they were a process of planning, promotion and promotion by the respective national States; This implies that the market itself was not the driving force behind these enclaves, but that it was an act planned by the respective secretariats or ministries of economy, planning, urban development and / or tourism.

\section{References}

Academia Internacional de Turismo de Montecarlo (1970). Diccionario turístico internacional. Edición española.- Monte Carlo: en $8^{\circ}$ mayor tela editorial.
Acerenza, M. A. (1986). Administración del turismo. Vol. 1. Ed. Trillas. México,

Arrillaga, J. I. (1995). Sistema de política turística. Aguilar. España.

Baños, Z. J. (2008). Atractivos turísticos del centro histórico de Santiago de Cuba. Ciencia en su PC, (1),72-79. [fecha de Consulta 2 de Abril de 2020]. ISSN: 1027-2887. Disponible en: https://www.redalyc.org/articulo.oa? $\mathrm{id}=1813 / 1$ 81320674009

Bormann,

A.

LehrevomFremdenverkehr:

Verkehrswissenschaftliche

Lehrmittelgesellschaft bei d. Deutschen

Reichsbahn. Berlín, Alemania.

Camelo, Octavio (2014). El impacto del crecimiento y desarrollo económico en el proceso de urbanización, Caso.- Municipio de Bahía de Banderas, Nayarit. Edit. UNAM. México.

Camelo, Octavio. y Rodríguez, Juan. (2018). Why tequila is named tequila? An approach from the regional history. En: Ecorfan-México. 9-20. Pág. 15-28. Edit. Ecorfan-Journal. México.

Ceballos, L. (2007). Ecoturismo, Las Cañadas. México.

CEPAL (2020). América latina y el Caribe ante la pandemia del COVID-19, efectos económicos y sociales. Edit. CEPAL.

Chávez, E. S., Chávez, E. S., \& Cerdan, L. M. (2019). El Turismo en Cuba: Desarrollo, Retos y Perspectivas/Tourism in Cuba: Development, Challenges, Perspectives. ROSA DOS VENTOS-Turismo e Hospitalidade, 11(1).

Chávez, E. S., Chávez, E. S., \& Cerdan, L. M. (2019). Tourism in Cuba: Development, Challenges, Perspectives. ROSA DOS VENTOS-Turismo e Hospitalidade, 11(1).

Cortés, W. R \& Muñoz, M. A. (2016). Modelo de orientación al turismo. (Pág. 9) Seminario de tesis. Facultad de Economía y Negocios. Universidad de Chile. Santiago de Chile. http://repositorio.uchile.cl/bitstream/handle/225 0/140447/Modelo\%20de\%20Orientaci\%C3\%B 3n\%20al\%20Turismo\%20-

$\% 20$ Cortes $\% 20 \mathrm{y} \% 20 \mathrm{Mu} \% \mathrm{C} 3 \% \mathrm{~B} 1$ oz.pdf?seque nce $=1$

De la Torre, P. O. (1997). El turismo. Fenómeno social. $2^{a}$ Ed. México, D. F. 
Fuentes, M. A. (2016). Aproximación teórica del objeto de estudio del turismo. Revista Siembra (3) 105-110. ISSN: 1390-8928. Universidad Central de Ecuador. Quito, Ecuador. Recuperado de: file://C:/Users/Eusebio/Downloads/DialnetAproximacionTeoricaDelObjetoDeEstudioDelT urismo-6140336\%20(5).pdf

Glücksmann, R. (1929). Die Betriebswirtschaft des Hotels (Hotel Administratión) In: Industrie und Handelskammer Berlin. Fremdenverkehr. Berlin, p. 360-398.

González, Juan y Villa, José (2002). Reflexiones para el análisis regional social. En: Acevedo, Antonio y Navarro, Lenin. Economía y desarrollo regional en México. Pag. 85-110. Edit. UMSNH, UdeG, AMCE, CEDN. México.

González, Y. R., Ahu, M. E. A., Sori, Y. A., \& González, M. M. (2019). Procedimiento de costeo basado en actividades en instalaciones hoteleras del destino turístico Jardines del Rey/Procedure of activty based costing in hotels of touristic destin Jardines del Rey. Universidad\&Ciencia, 8(3), 113-123.

Guerrero, R. R. (2010). Ecoturismo Mexicano: la promesa, la realidad y el futuro. Un análisis situacional mediante estudios de caso. El periplo Sustentable, núm. 18, enero-junio, pp. 37-67. Universidad Autónoma del Estado de México, Toluca, México. Recuperado de: https://www.redalyc.org/pdf/1934/1934144230 02.pdf

Hunziker W., Krapf K. (1942). Fundamentos de la Teoría General del Turismo. Alianza, Madrid, España.

Ibáñez, P. R. M \& Cabrera, V. C. (2011). Teoría general del turismo: un enfoque global $\mathrm{y}$ nacional. Editorial Serie Didáctica, Universidad Autónoma de Baja California Sur.

Jafari, J. (1977). Annals of Tourism Research V|Sp. No.): 6- 11. Editors: Jafar, Jafari \& J.R. Brent, Ritchie. (Pag. 15) Wisconsin, Stout, USA.

Jafari, J. ; \& Ritchie, J. R. B. (1981). Toward a Framework For Tourism Education: Problems and Prospects. Annals of Tourism Research, VIII (I): 13-34. Wisconsin-Stout University, USA.

Magliulo, A. (2015). Teoría económica del turismo e della rendita turística, de Michelle Troisi (1955). Pág. 34, editrice Aracne; (1 ${ }^{\mathrm{a}}$. edizione): gennaio. ISBN: 978-88-548-8082-5 Bari, Universitá di Bari; Roma, Italia.
Mathieson A. \& Wall G. (1982). Tourism: Económic Physical and social impacts. Editoral Londres: Longman. Londres, Inglaterra.

Ministerio de Turismo de Cuba. (2018) Infotur Cienfuegos. Recuperado de: https://www.cuba.travel/destinos/cienfuegos

Morgenroth, O. (1929). Fremdenverkehr. Citado en Sociología del Turismo (Hans Joachin Knebel) Hispano Europea. Barcelona. 1974.

Moya, B. V., Cabrera, A., Castillo, L., \& Rojo, J. (2007). Varadero ante el cambio global medio ambiental. Cambios globales en el ambiente y desarrollo sustentable en América Latina, 33.

Muñoz, de E. F. (1992). Tesis doctoral: Crítica de la economía turística: enfoque de oferta versus enfoque de demanda. (Pág. 24). Edit. Universidad Complutense de Madrid. Universidad Complutense de Madrid; España.

Oficina Nacional de Estadística e Información. (2019). Anuario Estadístico 2018 Cienfuegos. Recuperado de: http://www.one.cu/aed2018/27Cienfuegos/13\% 20Turismo.pdf

Oficina Nacional de Información Turística. (2020). Ministerio de Turismo de Cuba. Recuperado http://www.infotur.cu/destino.aspx?iddest=3

OMT (2019). Panorama del turismo internacional. Edit. OMT-UNWTO. Consultado 07 de mayo de 2020. Url: file:///C:/Users/Jos\%C3\%A9\%20Octavio\%20C amelo/Downloads/9789284421237.pdf

Organización Mundial del Turismo (1994). Recomendaciones sobre estadísticas de turismo. Madrid, España.

Pérez Guilarte, Y. (2014). Nuevas tendencias en turismo cultural. El papel de la investigación turística en ciudades patrimoniales: los casos de Santiago de Compostela y la Habana Vieja.

Robinson, Willian (2013). Una teoría sobre el capitalismo global, Edit. Siglo XXI. México.

Rodríguez, G. J. (2017). Polo Turístico De Varadero. Situación Actual; Retos y Perspectivas. (Área Turística Varadero Hoy; Desafíos y Perspectivas.). Recuperado de: https://ssrn.com/abstract=3045232 http://dx.doi.org/10.2139/ssrn.3045232

Sancho, A. (1997). Introducción al turismo. Edit. Organización Mundial del Turismo.

CAMELO-AVEDOY, José Octavio, RODRÍGUEZHERNÁNDEZ, Eusebio and RODRÍGUEZ ALVAREZ, Nely. Tourism and regional development as an expression of the globalization. Case.- Mexico-Cuba. ECORFAN Journal-Spain. 2020 
Schullern, H. (1911). Turismo y economía nacional. Jena, Austria.

Secretaria de Turismo (2004). Serie Turismo Alternativo, México, D.F.

Secretaría de Turismo (2004). Turismo alternativo: una nueva forma de hacer turismo. Fascículo 1, México, D.F. Recuperado de: https://www.jjcano.com/wpcontent/uploads/2011/01/1

1_conceptualizacion_turismo_alternativo1.pdf

Secretaría de Turismo, (2020). Resultados de la actividad turística de enero de 2020. DATATUR (Análisis integral del turismo). Subsecretaría de planeación y política turística. Recuperado de: https://www.datatur.sectur.gob.mx/SitePages/ve rsionesRAT.aspx

Stradner, J. (1917). Der Fremdenverkehr, Aufl; Graz, Berlín, Alemania

ToseeMéxico (2010). Zonas turísticas de México. Recuperado de: https://www.toseemexico.com/destinosturismo-mexico.htm

Troisi, M. (1942). La rendita turística: teoría e fatti, Bari, Universitá di Bari. Roma, Italia.

Vidal, Gregorio (2016). La economía mundial y los procesos de integración y regionalización. Edit UAM. México.

Villa, José (2003). Una propuesta de criterios para una política de desarrollo social regional para el estado de colima. Edit. UniCol. México.

Viloria, C. N. E. (2012). Desarrollo turístico y su relación con el transporte. Gestión Turística núm. 17, p.p. 23-36. Universidad Austral de Chile. Valdivia, Chile. Recuperado de: https://www.redalyc.org/pdf/2233/2233242040 02.pdf 